\title{
Meat quality of heifers finished on pasture with tropical grass and supplemented with glycerin
}

\author{
Robério Rodrigues Silva ${ }^{1}$, Livia Maria Araújo Macedo Facuri ${ }^{1}$, Gleidson Giordano
}

Pinto de Carvalho ${ }^{2}$, Fabiano Ferreira da Silva ${ }^{3}$, Julliana Izabelle Simionato ${ }^{4}$, Claudia Batista Sampaio, Lais Santana Bezerra ${ }^{2}$, Rodolpho Martin do Prado ${ }^{5}$, Ivanor Nunes do Prado ${ }^{5}$, Ana Paula Gomes da Silva ${ }^{1}$ Maria Leonor Garcia Melo Lopes de Araujo ${ }^{2}$, and Bruna Mara Aparecida de Carvalho ${ }^{6}$

${ }^{1}$ State University of Southeast Bahia, Departamento de Estudos Básicos e Instrumentais. Itapetinga, BA, Brazil

${ }^{2}$ Federal University of Bahia, Departamento de Zootecnia. Salvador - BA, Brazil

${ }^{3}$ State University of Southeast Bahia, Departamento de Tecnologia Rural e Animal. Itapetinga, BA,

${ }^{4}$ Technological University of Paraná, Londrina, PR, Brazil

${ }^{5}$ State University of Maringá - PR, Brazil

${ }^{6}$ Federal University of Minas Gerais, Institute of Agricultural Sciences, Montes Claros, MG, Brazil.

\begin{abstract}
R.R. Silva, L.M.A. M. Facuri, G.G.P. Carvalho, F.F. Silva, J.I. Simionato, C.B. Sampaio, L.S. Bezerra, R.M. Prado, I.N. Prado, A.P.G. Silva, M.L.G.M.L. Araujo, and B.M.A. Carvalho. 2017. Meat quality of heifers finished on pasture with tropical grass and supplemented with glycerin. Cien. Inv. Agr. 44(3): 320-332. Glycerin is an organic compound with an alcoholic function and can be esterified into fatty acids to form triglycerides. Due to the increasing availability of glycerin, studies that determine the best level of its inclusion in diets for ruminants are needed. This study evaluated the effects of glycerin supplementation on the proximate composition and fatty acid profile of the longissimus lumborum of heifers fed on Brachiaria brizantha pasture. Thirty-six heifers were distributed in a totally randomized design with four treatments (G0.0 = without glycerin, G4.6 $=4.6 \%$ glycerin, G9.3 $=9.3 \%$ glycerin and $\mathrm{G} 14.3=14.3 \%$ glycerin). The addition of glycerin decreased the tetradecanoic and octadecanoic fatty acids but increased the pentadecanoic, heptadecanoic, heptadecenoic, eicosanoic, eicosatetraenoic and docosatetraenoic fatty acids. The saturated (SFA), monounsaturated (MUFA) and omega-3 (n-3) fatty acid concentrations were similar across the diets. However, the polyunsaturated (PUFA) concentrations and the PUFA:MUFA and n-6:n-3 ratios increased with the inclusion of glycerin in the diet. Glycerin levels up to $14.3 \%$ (corresponding to a substitution of $50.5 \%$ of corn for this byproduct as an energy source) did not alter the proximate composition of the meat but improved the fatty acid profile of the longissimus lumborum muscle and, consequently, increased the meat quality, potentially providing benefits for human health.
\end{abstract}

Keywords: Biodiesel, CLA, glycerol, omega-3, polyunsaturated.

Received August 09, 2017. Accepted November 09, 2017.

Corresponding author: rrsilva.uesb@hotmail.com 


\section{Introduction}

The rapid expansion of the biodiesel industry over the past decade has increased glycerin availability. For each hundred $\mathrm{kg}$ of biodiesel, an average of ten $\mathrm{kg}$ of crude glycerin is produced (Johnson \& Taconi, 2007) as a byproduct. The increase in the availability of glycerin has driven prices down and contributed to excess production. This byproduct may be used for other purposes, such as for animal feed (Eiras et al., 2014, Cruz et al., 2014, Moreira et al., 2016, San Vito et al., 2015, Silva et al., 2014, Strada et al. 2015).

Glycerin is an organic compound with an alcoholic function, and it can be esterified to fatty acids to form triglycerides. Glycerol is the main component of glycerin, which also contains small amounts of ash, water and methanol (Eiras et al., 2014). Glycerol is metabolized by ruminal microorganisms and increases the total volatile fatty acid content in the rumen (El-Nor et al., 2010). Because it has gluconeogenic properties (Donkin et al., 2009), glycerol could potentially improve carcass and meat quality grades (Eiras et al., 2014, Françozo et al., 2013).

Glycerin supplementation could increase lipogenesis and thus increase marbling and subcutaneous fat (Parsons et al., 2009). Glycerin may also be converted into glucose in the livers of cattle. Thus, the glucose supply in bulls supplemented with glycerin may foster a rise in lipogenesis. However, other studies noted a linear decrease in marbling scores and subcutaneous fat when glycerin was included in the diets of cattle, which could negatively affect the carcass grades (Mach et al., 2009, Parsons et al., 2009).

As mentioned by Destefanis et al. (2000), statistical analysis of many heterogeneous data obtained through classic methods provides information for evaluating and understanding each variable. Although an analytical method, this approach neither reveals the relation between the variables nor allows the grouping of samples when they have homogeneous characteristics. Therefore, Karlsson (1992) suggested the evaluation of meat quality through correlated characteristics using principal component analysis. This study evaluated the effect of glycerin on the proximate composition and fatty acid profile in the longissimus lumborum of heifers supplemented while grazing on Brachiaria brizantha cultivar Marandu pasture.

\section{Materials and methods}

\section{Location, animals and experimental diets}

This experiment was approved by the Department of Animal Science (approval number 17/2012) of the State University of Bahia (CIOMS/OMS, 1985). The experiment lasted $135 \mathrm{~d}$ and was preceded by a 14-d adaptation period during which the animals were adapted to the diets, handling procedures and facilities.

The heifers were grazed on $B$. brizantha cultivar Marandu pasture. The total experimental area used was 18 ha, which was divided into ten paddocks of approximately 1.8 ha each for rotational grazing. Thirty-six 20-month-old crossbred heifers (average initial body weight $264 \pm 12 \mathrm{~kg}$ ) were distributed in a totally randomized design with four treatments and nine replicates as follows: G0.0 = control, G4.6 $=4.6 \%$ glycerin, G9.3 $=9.3 \%$ glycerin and G14.3 $=14.3 \%$ glycerin (based on the dry matter of the total diet); glycerin replaced $16.1 \%, 33.0 \%$ and $50.5 \%$ of the corn grain, respectively.

The supplement was provided to the heifers once daily (10:00 h) in plastic troughs, and because the experiment was conducted in a grazing system, the animals were kept in groups as described by Neto et al. (2015), Pouzo et al. (2016) and Wright et al. (2015). Animals in each treatment group were kept in a separate paddock for an occupation period of $7 \mathrm{~d}$. Supplementation with glycerin was provided to the nine animals in each group, and levels were calculated according to the amount ingested per heifer. As with other studies (Barbero 
et al., 2015, San Vito et al., 2015) for animals kept in groups on pasture, we estimated the nutritional and productive parameters in each animal individually through the supply of LIPE® capsules and the use of titanium dioxide in the supplement according to Titgemeyer et al. (1997, 2001).

The glycerin used in this study was supplied by a soy-diesel company (BIOPAR ${ }^{\circledR}$-Bioenergia do Paraná LTDA., Paraná State, Brazil) (Table 1). Four levels of glycerin were used to replace the corn grain (Table 2). The diets were formulated to be isonitrogenous and isoenergetic and to meet the nutritional requirements of growing heifers (NRC, 2000). The concentrate was formulated with specific mineral supplements (Table 2) for heifers and was composed of corn, soybean meal and different levels of glycerin.

Table 1. Chemical composition of glycerin used in heifer diets.

\begin{tabular}{lc}
\hline Parameters & Results \\
\hline Water $\left(\mathrm{mg} \mathrm{kg}^{-1}\right)$ & 232 \\
Ash (\%) & 4.76 \\
Glycerol (\%) & 81.20 \\
Methanol (\%) & 0.33 \\
Sodium (mg kg-1) & $11,634.40$ \\
Potassium $\left(\mathrm{mg} \mathrm{kg}^{-1}\right)$ & 79.10 \\
Chloride $\left(\mathrm{mg} \mathrm{kg}^{-1}\right)$ & 35.80 \\
Magnesium $\left(\mathrm{mg} \mathrm{kg}^{-1}\right)$ & 16.30 \\
Phosphorus $\left(\mathrm{mg} \mathrm{kg}^{-1}\right)$ & 239.80 \\
Gross energy $\left(\mathrm{kcal}^{-1}\right)$ & 3.400 \\
\hline
\end{tabular}

WWater content was determined by the Karl Fischer method at the Institute of Technology of Paraná (TECPAR).

The pasture was evaluated every $28 \mathrm{~d}$ (Table 2), and the availability of the dry matter (DM) was determined according to McMeniman (1997). The daily residual biomass (RB) was estimated using the double-sampling method (Wilm et al., 1994). Prior to cutting the samples, the DM of the biomass from the sample was estimated visually. The equation proposed by Gardner (1986) was utilized to calculate the forage biomass (expressed in $\left.\mathrm{kg} \mathrm{ha}^{-1}\right)$.
The forage, ingredients and concentrate samples were pre-dried in a forced-ventilation oven at 65 ${ }^{\circ} \mathrm{C}$ for $72 \mathrm{~h}$, processed with a Wiley cutting mill (Tecnal, Piracicaba City, São Paulo State, Brazil) with a 1-mm sieve, stored in plastic containers and sealed properly prior to laboratory analysis, which was conducted at the Laboratory of Feed Analyses and Animal Nutrition of the State University of Bahia (Table 2).

The dry matter (DM; Method 930.15), crude protein (CP; Method 976.05) and ether extract (EE, Method 2003.05) levels were determined according to the method of the Association of Official Analytical Chemists - AOAC (2006). The organic matter (OM) content was calculated as the difference between the DM and ash contents by incineration in an oven at $550{ }^{\circ} \mathrm{C}$ for $5 \mathrm{~h}$ (AOAC, 2006). The methods described by Mertens (2002) were used to determine the neutral detergent fiber (NDF) and acid detergent fiber (ADF) contents. Total carbohydrates (TCs) were obtained by the following equation proposed by Sniffen et al. (1992): $\mathrm{TC}=100-(\% \mathrm{CP}+\% \mathrm{EE}+\% \mathrm{MM})$. Non fiber carbohydrates (NFCs) were determined by the difference between the TC and the NDF. The total digestible nutrient (TDN) content of the diets was obtained using the methodology described by Kearl (1982).

\section{Slaughter and sample collection}

At the end of confinement and after resting and a 14-h period of fasting from solids, the heifers were slaughtered in a commercial slaughterhouse (Confrigo Frigorífico Ltd., Vitória da Conquista, BA, Brazil) by concussion stunning (air gun), followed by bleeding, skinning and evisceration. The slaughtering procedures followed the Sanitary and Industrial Inspection Regulation for Animal Origin Products (Brasil, Ministério Pecuária e Abastecimento, 2000).

After dressing and evisceration, the carcasses were split into two identical longitudinal halves 
Table 2. Ingredient composition (\% of DM) of the concentrate and chemical composition of Brachiaria brizantha cv. Marandu, including the total availability of the dry and residual biomass, allotment space, accumulation rate and forage availability and the chemical compositions of the concentrates.

\begin{tabular}{|c|c|c|c|c|c|}
\hline \multirow{2}{*}{ Ingredient (\% DM) } & & \multicolumn{4}{|c|}{ Level of replacement (\% DM) } \\
\hline & & $0^{\dagger}$ & 16.12 & $32.99^{\S}$ & $50.49^{\pi}$ \\
\hline Soybean meal & & 20.57 & 23.69 & 26.94 & 30.30 \\
\hline Ground corn & & 77.65 & 61.94 & 45.60 & 28.63 \\
\hline Glycerin & & 0.00 & 12.52 & 25.62 & 39.21 \\
\hline Mineral salt ${ }^{\#}$ & & 1.77 & 1.80 & 1.83 & 1.88 \\
\hline \multirow{2}{*}{ Ingredients } & \multirow{2}{*}{ Brachiaria brizantha } & \multicolumn{4}{|c|}{ Glycerin levels (\% DM) } \\
\hline & & $\mathrm{G} 0.0^{\dagger}$ & $\mathrm{G} 4.6^{ \pm}$ & G9.3 $3^{\S}$ & G14.3" \\
\hline Dry matter (\%) & 35.97 & 91.7 & 92.4 & 91.8 & 92.2 \\
\hline Crude protein ${ }^{\dagger \dagger}$ & 5.62 & 21.1 & 22.1 & 23.3 & 24.6 \\
\hline Ether extract ${ }^{\dagger \dagger}$ & 1.20 & 2.47 & 2.72 & 2.79 & 2.82 \\
\hline Total carbohydrates ${ }^{\dagger \dagger}$ & 84.3 & 72.8 & 71.0 & 68.9 & 66.7 \\
\hline Non fiber carbohydrates ${ }^{\dagger \dagger}$ & 19.1 & 58.9 & 57.3 & 55.5 & 53.4 \\
\hline Gross energy $\left(\mathrm{kcal} \mathrm{kg}^{-1}\right)^{\sharp}$ & 4.22 & 4.30 & 4.24 & 4.25 & 4.19 \\
\hline Neutral detergent fiber ${ }^{\dagger \dagger}$ & 66.5 & 13.9 & 13.7 & 13.4 & 13.3 \\
\hline Acid detergent fiber ${ }^{\dagger \dagger}$ & 40.5 & 3.59 & 3.79 & 3.92 & 4.17 \\
\hline Mineral matter ${ }^{\dagger \dagger}$ & 8.87 & 3.66 & 4.15 & 4.99 & 5.82 \\
\hline Total digestible nutrients ${ }^{\dagger \dagger}$ & 51.0 & 63.7 & 60.6 & 61.4 & 61.4 \\
\hline Total availability of DM $\left(\mathrm{kg} \mathrm{ha}^{-1}\right)$ & 3103 & - & - & - & - \\
\hline Residual biomass ( $\mathrm{kg} \mathrm{DM} \mathrm{ha}^{-1}$ day $^{-1}$ ) & 111 & - & - & - & - \\
\hline Allotment rate $\left(\mathrm{AU} \mathrm{ha}^{-1}\right)$ & 1.33 & - & - & - & - \\
\hline Accumulation rate $\left(\mathrm{kg} \mathrm{DM} \mathrm{ha}^{-1}\right.$ day $\left.^{-1}\right)$ & 27.7 & - & - & - & - \\
\hline Forage supply (kg DM $100 \mathrm{~kg}^{-1} \mathrm{LW}^{-1}$ day $\left.^{-1}\right)$ & 23.2 & - & - & - & - \\
\hline
\end{tabular}

Without glycerin; ${ }^{\star} 4.6 \%$ glycerin $(\% \mathrm{DM}) ; \$ 9.3 \%$ glycerin $(\% \mathrm{DM}) ;{ }^{\circledR} 14.3 \%$ glycerin $(\% \mathrm{DM})$. "Supplied per kilogram of product: calcium - $175 \mathrm{~g}$; phosphorus - $60 \mathrm{~g}$; sodium $-107 \mathrm{~g}$; sulfur - $12 \mathrm{~g}$; magnesium - $5 \mathrm{~g}$; cobalt $-107 \mathrm{mg}$; copper $-1.30 \mathrm{~g}$; iodine - 70 $\mathrm{mg}$; manganese $-1000 \mathrm{mg}$; selenium $-18 \mathrm{mg}$; zinc $-4.0 \mathrm{~g}$; iron $-1.4 \mathrm{~g} .{ }^{\dagger}$ Values represent a percentage of the dry matter; ${ }^{\mathrm{t}} \mathrm{The}$ gross energy was determined using a bomb calorimeter.

through the sternum and spine. The half carcasses were identified, transported to a cold chamber and maintained at $2{ }^{\circ} \mathrm{C}$ for $24 \mathrm{~h}$. The section between the $10^{\text {th }}$ and $13^{\text {th }}$ ribs on the right half of the carcass was removed according to the methodology described by Hankins \& Howe (1946) and adapted by Muller (1987).

\section{Proximate composition analysis and fatty acid profile}

Analyses of the longissimus lumborum samples were performed two months after sampling using samples from the right side of the carcass after a cross-section cut was made between the $12^{\text {th }}$ and $13^{\text {th }}$ ribs. The longissimus lumborum samples were ground, homogenized and analyzed in triplicate.

The proximate compositions of the longissimus lumborum samples in terms of moisture, ash and crude protein were determined according to the AOAC (2006) methods. Total lipids were extracted by the Bligh and Dyer (1959) method.

Triacylglycerols (TAGs) were transesterified to obtain fatty acid methyl esters (FAMEs) via triacylglycerol methylation according to the ISO 
(1978) method. The FAMEs were analyzed in a gas chromatograph (Varian, USA) equipped with a flame ionization detector and a fused silica capillary Select FAME column (CP-7420, 100 m, 0.25 $\mathrm{mm}$ and $0.39 \mu \mathrm{m}$ o.d. Varian, USA). The column temperature was programmed for $165^{\circ} \mathrm{C}$ for 18 $\min , 180^{\circ} \mathrm{C}\left(30^{\circ} \mathrm{C} \mathrm{min}^{-1}\right)$ for $22 \mathrm{~min}$, and $240{ }^{\circ} \mathrm{C}$

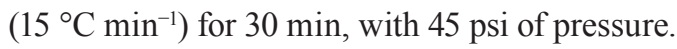
The injector and detector were kept at $220^{\circ} \mathrm{C}$ and $245^{\circ} \mathrm{C}$, respectively. The gas flows (White Martins, São Paulo, Brazil) were $1.4 \mathrm{~mL} \mathrm{~min}^{-1}$ for the carrier

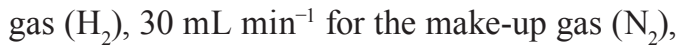
and $30 \mathrm{~mL} \mathrm{~min}^{-1}$ and $300 \mathrm{~mL} \mathrm{~min}^{-1}$ for $\mathrm{H}_{2}$ and the synthetic flame gas, respectively. The sample was injected using a split mode $1 / 80$. Fatty acids (FAs) were identified by comparing the relative retention times of the FAME peaks of samples spiked with FAME standard 189-19 (Sigma Company, St. Louis, MO, USA). Peak areas were determined using Star software (Varian, Walnut Creek, CA, USA), as described by Simionato et al. (2010). Data were expressed as percentages of the normalized fatty acid area (Table 3).

\section{Statistical analysis}

The experimental design was completely randomized, with four treatments and eight replicates using the following model:
$\mathrm{Y}_{\mathrm{ij}}=\mu+\mathrm{T}_{\mathrm{i}}+\mathrm{e}_{\mathrm{ij}}$

where $Y_{i j}=$ the observed value of the dependent variable, $\mu=$ the overall mean, $T_{i}=$ the effect of treatment $\mathrm{i}\left(\mathrm{i}=1\right.$ to 5 ), and $\mathrm{e}_{\mathrm{ij}}=$ the experimental error. The univariate statistical analysis was performed with SAS (2009), and the characteristics in this study were tested for normality. Data that showed normal distributions were analyzed by regression equations following the MIXED procedure to determine the linear and quadratic effects of glycerin. The treatment means were computed with the LSMEANS option. The treatment means were declared significant at $\mathrm{P}<0.01$.

The values of parameters obtained from the fatty acid profile analysis in heifers fed diets with glycerin consisted of multivariate data sets arranged in a matrix $(36 \times 36)$ and interpreted using principal component analysis. The analysis was performed with the Statistical Analysis System (SAS $9.0^{\circledR}, 2009$ ) using the data-centric average.

\section{Results}

The moisture, ash, crude protein and total lipid concentration averages were 74.9, 1.10, 22.7 and $1.16 \%$, respectively (Table 4$)$. A linear reduction of C14:0- tetradecanoic acid (24.4\%) was observed

Table 3. Fatty acid profiles of glycerin, roughage, forage and concentrate.

\begin{tabular}{lcccccc}
\hline \multirow{2}{*}{ Fatty acid } & B. brizantha & Glycerin & \multicolumn{3}{c}{ Glycerin levels (\% DM) } \\
\cline { 4 - 7 } & & & G0.0 & G4.6 & G9.3 & G14.3\% \\
\hline C16:0 & 30.25 & 12.24 & 13.18 & 13.99 & 14.34 & 15.38 \\
C17:0 & 5.59 & 4.97 & 4.48 & 3.34 & 3.68 & 4.29 \\
C18:0 & 11.77 & 25.77 & 39.13 & 39.03 & 40.49 & 32.11 \\
C18:1n9 & 22.81 & 51.62 & 39.92 & 41.36 & 39.12 & 45.14 \\
C18:2n6 & 25.60 & 4.06 & 2.07 & 1.62 & 1.50 & 2.47 \\
C 21:0 & 2.87 & 1.33 & 0.70 & 0.24 & 0.34 & 0.25 \\
C 22:2n6 & 1.11 & - & 0.52 & 0.41 & 0.53 & 0.36 \\
C 22:6n3 & 1.09 & - & - & - & - & - \\
\hline
\end{tabular}

Without glycerin; ${ }^{\$} 4.6 \%$ glycerin (\% DM); ${ }^{\$} 9.3 \%$ glycerin $(\% \mathrm{DM}) ;{ }^{\circledR} 14.3 \%$ glycerin $(\% \mathrm{DM}) .16: 0$ - Hexadecanoic acid; $17: 0$ Heptadecanoic acid; 18:0 - Octadecanoic acid; 18:1n9 - Octadecenoic acid; 18:2n6 - octadecadienoic acid; 21:0 - Heneicosanoic acid; 20:5n3 Eicosapentaenoic acid (EPA), 22:2n6 - Docosadienoic acid 13, 16; 22:6n3 - Docosahexaenoic acid (DHA). 
Table 4. Proximate composition of the longissimus lumborum muscle from heifers finished in the pasture system and supplemented with glycerin in their diets.

\begin{tabular}{|c|c|c|c|c|c|c|c|}
\hline \multirow{2}{*}{ Item $(\% \mathrm{NM})$} & \multicolumn{4}{|c|}{ Glycerin levels (\% DM) } & \multirow{2}{*}{$\mathrm{SEM}^{\#}$} & \multicolumn{2}{|c|}{ P Values } \\
\hline & $\mathrm{G} 0.0^{\dagger}$ & G4.6 & G9.3 & G14.3 & & Linear & Quadratic \\
\hline Moisture & 74.5 & 74.8 & 75.0 & 75.4 & 0.26 & 0.22 & 0.48 \\
\hline Ash & 1.13 & 1.09 & 1.10 & 1.11 & 0.09 & 0.25 & 0.33 \\
\hline Crude protein & 22.8 & 22.9 & 22.9 & 22.5 & 0.24 & 0.71 & 0.86 \\
\hline Total lipids & 1.13 & 1.24 & 1.20 & 1.08 & 0.08 & 0.34 & 0.60 \\
\hline
\end{tabular}

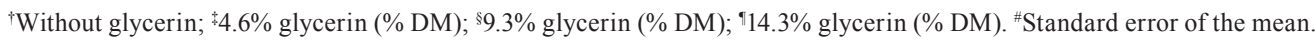

with the inclusion of glycerin in the diet. However, increasing levels of glycerin increased the C15:0 (pentadecanoic acid) fatty acid concentration (Table 5), linearly increased the $\mathrm{C17:0}$ (heptadecanoic acid) and C17:1 (heptadecenoic acid) fatty acid concentrations, and linearly decreased the C18:0 (octadecanoic acid) fatty acid concentration in the longissimus lumborum.

No effect was observed on the unsaturated fatty acid concentrations in the $\mathrm{C} 18$ series. Thus, no difference was detected in the $\mathrm{c} 9, \mathrm{c} 12$ octadecadienoic acid concentration of the meat (C18:2) with the increasing dietary crude glycerin. Additionally, no difference was observed in the c9,t11-octadecadienoic acid concentration of the meat (C18:2) with increasing dietary crude glycerin.

The levels of the C20:0 (eicosanoic acid), C20:4n-6 (eicosatetraenoic acid) and C22:4n-6 (docosatetraenoic acid) fatty acids in the longissimus lumborum increased linearly with the addition of increasing amounts of glycerin to the heifer diets. The saturated fatty acid (SFA) and MUFA concentrations were similar (Table 5). The PUFA concentrations in the longissimus lumborum increased linearly. The concentration of the sum of the n-6 fatty acid series increased $45 \%$. The $\mathrm{n} 6: \mathrm{n} 3$ ratio in the longissimus lumborum increased linearly from 3.6 to 5.37 .

Figure 1 and Table 6, respectively, show the PCA scores and estimates of the eigenvalues associated with the studied variables that are associated with the fatty acid profiles in the muscle samples of longissimus lumborum in the heifers fed diets supplemented with glycerin.

The principal component analysis showed that $92.57 \%$ of the variation of the results was explained by the first and second main components. Thus, contributions of the first (61.85\%) and second (30.72\%) principal components were observed.

Table 6. Principal component (PC), eigenvalues $\left(\lambda_{\mathrm{i}}\right)$, and percentage of variance explained by the component $(\%$ VCP) of the fatty acid studied in the longissimus lumborum of heifers supplemented with glycerin in the diet.

\begin{tabular}{ccccc}
\hline $\mathrm{I}$ & $\begin{array}{c}\text { Principal } \\
\text { component }\end{array}$ & $\lambda_{\mathrm{i}}$ & \% VCP & $\begin{array}{c}\text { \% VCP } \\
\text { (accumulated) }\end{array}$ \\
\hline 1 & $\mathrm{PC}_{1}$ & 2.6165 & 61.85 & 61.85 \\
2 & $\mathrm{PC}_{2}$ & 1.2995 & 30.72 & 92.57 \\
3 & $\mathrm{PC}_{3}$ & 0.3144 & 7.43 & 100.00 \\
4 & $\mathrm{PC}_{4}$ & 0 & 0.000 & 100.00 \\
5 & $\mathrm{PC}_{5}$ & 0 & 0.000 & 100.00 \\
6 & $\mathrm{PC}_{6}$ & 0 & 0.000 & 100.00 \\
7 & $\mathrm{PC}_{7}$ & 0 & 0.000 & 100.00 \\
. &. &. &. &. \\
. &. &. &. &. \\
. &. &. &. &. \\
35 & $\mathrm{PC}_{35}$ & 0 & 0.000 & 100.00 \\
\hline
\end{tabular}

To evaluate the discrimination of the fatty acid profile, the two main components (the first principal component (PC1) and $\mathrm{PC} 2$ ) were plotted (Figure 1). The score portion of the PC1 compared 
Table 5. Fatty acid percentage and sum of the longissimus lumborum in heifers finished in the pasture system and supplemented with glycerin in their diets.

\begin{tabular}{|c|c|c|c|c|c|c|c|c|}
\hline \multirow{2}{*}{ Fatty acid } & \multicolumn{4}{|c|}{ Glycerin levels (\% DM) } & \multirow{2}{*}{ SEM $^{\#}$} & \multicolumn{2}{|c|}{ P Value } & \multirow{2}{*}{$\mathrm{R}^{2}$} \\
\hline & $\mathrm{G} 0.0^{\dagger}$ & $\mathrm{G} 4.6^{\ddagger}$ & $\mathrm{G} 9.3^{\S}$ & G14.3" & & Linear & Quadratic & \\
\hline C 14:0 -Tetradecanoic & 2.99 & 2.75 & 2.40 & 2.26 & 0.09 & 0.01 & 0.92 & 0.55 \\
\hline C 14:1 -Tetradecenoic & 0.50 & 0.40 & 0.45 & 0.48 & 0.02 & 0.70 & 0.25 & - \\
\hline C 15:0 -Pentadecanoic & 0.37 & 0.46 & 0.46 & 0.53 & 0.02 & 0.01 & 0.74 & 0.89 \\
\hline C 15:1- Pentadecenoic & 0.21 & 0.21 & 0.17 & 0.19 & 0.01 & 0.10 & 0.65 & - \\
\hline C 16:0-Hexadecanoic & 25.0 & 24.8 & 25.8 & 25.6 & 0.39 & 0.29 & 0.83 & - \\
\hline C 16:1 -Hexadecenoic & 2.71 & 2.64 & 2.68 & 2.87 & 0.07 & 0.45 & 0.36 & - \\
\hline C 17:0 -Heptadecanoic & 1.04 & 1.18 & 1.32 & 1.69 & 0.05 & 0.001 & 0.07 & 0.99 \\
\hline C 17:1 -Heptadecenoic & 0.89 & 0.93 & 1.15 & 1.47 & 0.05 & 0.001 & 0.06 & 0.91 \\
\hline C 18:0 -Octadecanoic & 17.9 & 18.4 & 16.4 & 15.6 & 0.41 & 0.01 & 0.39 & 0.78 \\
\hline C $18: 1-n 7$ - cis- 11 Octadecenoic & 1.67 & 1.92 & 1.74 & 1.73 & 0.06 & 1.00 & 0.28 & - \\
\hline C 18:1-n9c-Octadecenoic & 40.2 & 39.9 & 39.9 & 39.6 & 0.40 & 0.07 & 0.91 & - \\
\hline C 18:1-n11t - Trans-Octadecenoic & 1.78 & 1.54 & 1.75 & 1.88 & 0.08 & 0.30 & 0.20 & - \\
\hline C 18:2-n6 - c9,c12 Octadecadienoic & 2.06 & 2.07 & 2.87 & 2.69 & 0.10 & 0.12 & 0.06 & - \\
\hline C 18:2-c9t11 - c9,t 11-Octadecadienoic & 0.16 & 0.14 & 0.15 & 0.11 & 0.25 & 0.03 & 0.09 & - \\
\hline $\begin{array}{l}\text { C } 18: 3-n 3 \text { - c9,c12,c15- } \\
\text { Octadecatrienoic }\end{array}$ & 0.49 & 0.54 & 0.45 & 0.46 & 0.01 & 0.26 & 0.61 & - \\
\hline C 18:3-n6 - c6,c9,c12-Octadecatrienoic & 0.10 & 0.11 & 0.09 & 0.10 & 0.00 & 0.60 & 0.46 & - \\
\hline C 20:0 Eicosanoic & 0.33 & 0.37 & 0.35 & 0.49 & 0.02 & 0.01 & 0.17 & 0.68 \\
\hline C 20:2-n6 - Eicosadienoic & 0.10 & 0.13 & 0.11 & 0.11 & 0.01 & 0.16 & 0.12 & \\
\hline C 20:4-n6 -Eicosatetraenoic & 0.55 & 0.66 & 0.75 & 0.99 & 0.05 & 0.01 & 0.50 & 0.95 \\
\hline C 20:5-n3 - Eicosapentaenoic & 0.25 & 0.19 & 0.31 & 0.28 & 0.01 & 0.07 & 0.54 & - \\
\hline C 22:0 - Docosanoic & 0.16 & 0.17 & 0.16 & 0.17 & 0.02 & 0.23 & 0.35 & - \\
\hline C 22:4-n6 - Docosatetraenoic & 0.19 & 0.19 & 0.22 & 0.46 & 0.01 & 0.01 & 0.53 & 0.99 \\
\hline C 22:6- $n 3$ - Docosahexaenoic & 0.27 & 0.27 & 0.26 & 0.28 & 0.01 & 0.58 & 0.12 & - \\
\hline $\mathrm{SFA}^{\dagger+}$ & 47.8 & 48.1 & 46.8 & 46.3 & 0.46 & 0.34 & 0.73 & - \\
\hline MUFA & 48.0 & 47.5 & 47.9 & 48.8 & 0.46 & 0.85 & 0.33 & - \\
\hline PUFA $^{\S \S}$ & 4.24 & 4.36 & 5.28 & 5.55 & 0.15 & 0.01 & 0.10 & 0.61 \\
\hline$n-6^{4 \pi}$ & 3.00 & 3.16 & 4.04 & 4.35 & 0.12 & 0.01 & 0.18 & 0.55 \\
\hline$n-3^{\# \#}$ & 0.83 & 0.87 & 0.78 & 0.81 & 0.03 & 0.31 & 0.10 & - \\
\hline PUFA:MUFA & 0.09 & 0.09 & 0.11 & 0.12 & 0.01 & 0.03 & 0.08 & 0.59 \\
\hline$n-6: n-3$ 赫 & 3.61 & 3.63 & 5.18 & 5.37 & 0.14 & 0.01 & 0.08 & 0.81 \\
\hline
\end{tabular}

${ }^{\dagger}$ Without glycerin; $\$ 4.6 \%$ glycerin $(\% \mathrm{DM}) ;{ }^{\$} 9.3 \%$ glycerin $(\% \mathrm{DM}) ;{ }^{\circledR} 14.3 \%$ glycerin $(\% \mathrm{DM})$. ${ }^{*}$ Standard error of the mean; ${ }^{\dagger}$ Saturated fatty acids; ${ }^{*}$ Monounsaturated fatty acids; ${ }^{\S}$ Polyunsaturated fatty acids; "Fatty acids $n$-6; "\#atty acids $n$ - 3 ; ${ }^{\dagger}$ PUFA:MUFA ratio; ${ }^{\prime \prime} n-6: n-3$ ratio.

to that of PC2, with a cumulative contribution of $92.57 \%$, was the easiest method for viewing the main trends defined in the different treatment samples. A tendency existed for separa- tion between the samples in accordance with the increased levels of glycerin in the diet. The increasing addition of glycerin was distinguished into three different groups (Figure 1). 


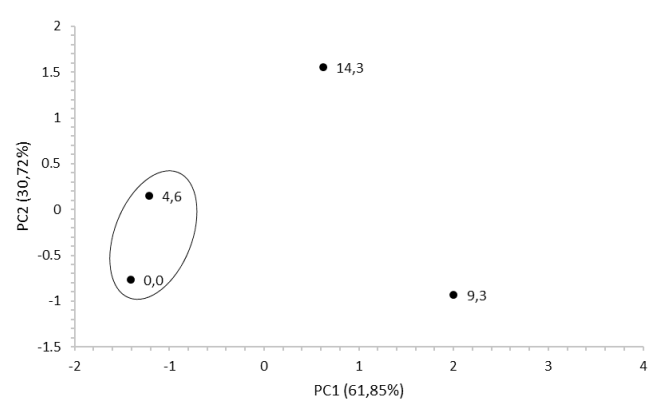

Figure 1. The first two principal components of the fatty acid profile analysis in the samples from the longissimus lumborum in heifers fed diets supplemented with glycerin $(0.0 ; 4.6 ; 9.3$ and 14.3$)$.

\section{Discussion}

The moisture, ash and crude protein levels were similar to those reported in the literature (Correia et al., 2016, Françozo et al., 2013, Rotta et al., 2009a, Rotta et al., 2009b). Rivaroli et al. (2016) investigated the effect of the different doses of an essential oil blend on meat quality and observed that the meat proximate compositions (moisture, ash, crude protein and total lipids) were unaffected by the addition of essential oils to the diet.

The lipid rates in the longissimus lumborum were low. We expected that the glucose produced by glycerin would increase the muscle lipids in the heifers due to an increase in the blood insulin concentration and lipogenesis. However, Eiras et al. (2014) reported a total lipid decrease in the longissimus lumborum of bulls fed glycerin $(0 \%, 6 \%, 12 \%$ and $18 \%$ of the DM). The low total lipid levels may be explained by the age of the heifers (young animals), which generally present lower total lipids and cholesterol in the meat (Rotta et al., 2009a).

The linear reduction of C14:0 acid (24.4\%) as glycerin increases in the diet is beneficial to human health (Webb and O'Neill, 2008) because this fatty acid is considered hypercholesterolemic (Scollan et al., 2006). Similarly, Eiras et al. (2014) reported a reduction in C14:0 in meat from bulls fed increasing levels of glycerin in the diet.

Fatty acids with an odd chain are present at low levels in mammals (Rotta et al., 2009b). In ru- minants, this acid is formed by de novo synthesis from propionic acid produced in the rumen by the fermentation process (Trabue et al., 2007). Thus, the increase in C15:0 in the longissimus lumborum may be attributed to the formation of propionic acid with the addition of glycerin in the diet (Lee et al., 2011, Trabue et al., 2007).

Variations in the C17:0 and C17:1 fatty acid levels may be attributed to the ruminal fermentation time. According to Trabue et al. (2007), 80\% of glycerin is completely metabolized in the rumen $24 \mathrm{~h}$ after feeding and is principally transformed into propionic acid, which may be used to form heptadecanoic acid in the meat.

The linear decrease of the C18:0 fatty acid concentration is thought to have a neutral effect on a hypercholesterolemic diet in humans (Webb and O'Neill, 2008). Moreover, this fatty acid represents 10 to $20 \%$ of the fats produced by ruminants (Valsta, Tapanainen, \& Männistö, 2005). High levels of octadecadienoic acid are present in corn, and therefore, its replacement resulted in lower octadecadienoic acid intake by the animals. The increasing dietary crude glycerin was in agreement with previous studies (Carvalho et al., 2014, Carvalho et al., 2015). This apparent contradiction may result from lower ruminal biohydrogenation, which results in greater absorption of fatty acids in the duodenum.

SFAs represented approximately $47 \%$ of the total fatty acids in the longissimus lumborum in heifers, whereas monounsaturated fatty acids (MUFA) represented $48 \%$ of the total fatty acids. The inclusion of glycerin in the ruminant diet had a low effect on the fatty acid composition in the longissimus lumborum (Eiras et al., 2014, Françozo et al., 2013). Indeed, the SFAs and the MUFAs of the longissimus lumborum bulls fed glycerin were lower than those evaluated in bulls from different crossbreeding systems finished in a feedlot (Ducatti et al., 2009, Rotta et al., 2009a). The values were similar for the SFAs, although the MUFAs were present at higher concentra- 
tions than reported by Françozo et al. (2013), who evaluated beef from Nellore cattle fed diets containing glycerin $(0 \%, 5 \%$ and $12 \%$ of the DM).

The PUFA concentrations ranged between 5 and $10 \%$ in the cattle finished in a feedlot (Rotta et al., 2009b). In some cases, the concentrations were greater than 10\% (Maggioni et al., 2009). From the perspective of human health, an increase in the PUFAs in the meat of ruminants is desirable because it is associated with increases in the n-3 and n-6 series of FAs (HMSO, 1994, Webb and O'Neill, 2008, Wood et al., 2008). As noted, the replacement of corn with glycerin in the diet of bulls finished in a feedlot significantly increased the PUFA percentage in the longissimus lumborum (Eiras et al., 2014, Zawadzki et al., 2013).

Increasing the n- 6 fatty acid concentration corroborated the results of Eiras et al. (2014), who found that the n- 6 percentage ranged between $3.4 \%$ and $5.0 \%$ with an increase of $46 \%$ due to glycerin inclusion in the diet of bulls finished in a feedlot. Diets with glycerin inclusion that present a n6:n3 ratio greater than 4 are considered beneficial to human health. Human diets are typically close to a ratio of 4. Similarly, Eiras et al. (2014) observed an increase in the n6:n3 ratio levels when 0 to $18 \%$ glycerin $(\% \mathrm{DM})$ was included in the diet of cattle. Thus, the inclusion of glycerin in the diet could be a useful tool for improving the $\mathrm{n} 6: \mathrm{n} 3$ ratio in meat from ruminants finished in a feedlot.

The numbers represented by component analysis demonstrated significant contributions of individual fatty acid variables to the total variability explained by the generated PCs. Hernandez et al. (2000) reported that the principal component analysis (PCA) is a multivariate statistical tool for obtaining a restricted group of measures that explain most of the variability of the measurements. According to the authors, the PCA also helps to evaluate the relations between variables and to compare the differences between groups of animals.
According to Cruz et al. (2012), the principal component analysis is determined by components that involve at least $80 \%$ of the total variation, thereby showing the importance of each variable studied and its effect on the total variation between observations.

$\mathrm{PC} 1$ could be discriminated by the glycerin levels in the diet, with samples with higher glycerin levels in the diet located at the negative end of PC1. Thus, three groups were formed with lower, intermediate and higher glycerin values. Pereira et al. (2016) used principal component analysis to evaluate the nutritional quality of meat from lambs fed diets containing cotton cake from biodiesel production. The authors found that two principal components explained $83.03 \%$ of the variance of the data according to the set of data analyzed. The increasing addition of cotton cake to the diets of the sheep affected the fatty acid compositions.

Similarly, Soliman et al. (2016) evaluated two different feed regimens for cattle to determine whether a significant difference existed in the fatty acid profiles across conventional grain-fed and grassfed beef and observed that the variances of PC1 and PC2 were 51.3 and $28.6 \%$, respectively. The cumulative proportion from $\mathrm{PC} 1$ to $\mathrm{PC} 4$ was $95.6 \%$, and all fatty acids contributed to PC1. Additionally, all fatty acids except C18:3n-6 contributed to PC2.

However, Bednárová et al. (2013) evaluated differences in the fatty acid composition and elemental composition of beef originating from grasslandbased production based on animal age and sex and observed that the first two PCs calculated accounted for $55.8 \%$ of the total data variance.

Therefore, the main conclusion is that glycerin levels up to $14.3 \%$, which corresponded to the substitution of $50.5 \%$ of the corn for this byproduct as an energy source, did not alter the proximate composition of the meat but improved the fatty acid profile of the longissimus lumborum muscle and, consequently, increased the meat quality, with benefits for human health. 


\section{Resumen}

R.R. Silva, L.M.A. M. Facuri, G.G.P. Carvalho, F.F. Silva, J.I. Simionato, C.B. Sampaio, L.S. Bezerra, R.M. Prado, I.N. Prado, A.P.G. Silva, M.L.G.M.L. Araujo, y B.M.A. Carvalho. 2017. Calidad de la carne de vaquillas terminadas en sistema de pastoreo tropical y suplementadas con glicerina. Cien. Inv. Agr. 44(3): 320-332. La glicerina es un compuesto orgánico con una función alcohólica que puede esterificarse en ácidos grasos para formar triglicéridos. Debido a su disponibilidad cada vez mayor, se necesitan estudios que indiquen el mejor nivel de inclusión en las dietas para los rumiantes. Este estudio evaluó los efectos de la glicerina sobre la composición próxima y el perfil de ácidos grasos de Longissimus lumborum de novillas suplementadas con pasto de Brachiaria brizantha. Se distribuyeron 36 vaquillas en un diseño totalmente aleatorizado con cuatro tratamientos $(\mathrm{G} 0.0=$ sin glicerina, G4.6 = 4,6\% de glicerina, G9.3 = 9.3\% de glicerina y G14.3 = 14.3\% de glicerina). La adición de glicerina disminuyó los ácidos grasos tetradecanoico y octadecanoico, pero aumentó los ácidos grasos pentadecanoico, heptadecanoico, heptadecenoico, eicosanoico, eicosatetraenoico y docosatetraenoico. Las concentraciones de ácidos grasos saturados (SFA), monoinsaturados (MUFA) y omega-3 (n-3) fueron similares en todas las dietas. Sin embargo, las concentraciones de poliinsaturados (PUFA) y los niveles de PUFA: MUFA y n-6: n-3 aumentaron con la inclusión de glicerina en las dietas. Los niveles de glicerina hasta 14.3\% (que corresponden a una sustitución del $50.5 \%$ de maíz por este subproducto como fuente de energía) no alteraron la composición proximal de la carne pero mejoraron el perfil de ácidos grasos del músculo Longissimus lumborum y, en consecuencia, aumentaron la carne calidad, potencialmente proporcionando beneficios para la salud humana.

Palabras clave: Biodiesel, CLA, glicerol, omega-3, poliinsaturados.

\section{References}

AOAC. 2006. Association of Official Analytical Chemists. Official Methods of Analysis. Inc., Arlington, VA, U.S.A.

Bednárová, A., J. Mocák, W. Gössler, M. Velik, J. Kaufmann, and L. Staruch, 2013. Effect of animal age and gender on fatty acid and elemental composition in Austrian beef applicable for authentication purposes. Chem. Pap. 67:274-283.

Barbero, R.P., E.B. Malheiros, T.L.R. Araújo, R.L.G. Nave, J.T. Mulliniks, T.T. Berchielli, A.C. Ruggieri, and R.A. Reis. 2015. Combining Marandu grass grazing height and supplementation level to optimize growth and productivity of yearling bulls. Anim. Feed Sci. Technol. 209:110-118.

Bligh, E.G., and W.J. Dyer. 1959. A rapid method of total lipid extraction and purification. Can. J. Biochem. Physiol. 37:911-917.
Carvalho, J.R., M.L. Chizzotti, E.M. Ramos, D. Machado Neto, L.S. Lopes, P.D. Teixeira, and M.M. Ladeira. 2014. Qualitative characteristics of meat from young bulls fed different levels of crude glycerin. Meat Sci. 96:977-983.

Carvalho, V.B., R.F. Leite, M.T.C. Almeida, J.R. Paschoaloto, E.B. Carvalho, D.P.D. Lanna, H.L. Perez, E.H.C.B. Van Cleef, A.C. Homem Junior, and J.M.B. Ezequiel. 2015. Carcass characteristics and meat quality of lambs fed high concentrations of crude glycerin in low-starch diets. Meat Sci. 110:285-292.

CIOMS/OMS. 1985. Council for International Organizations of Medical Services - International Guiding Principles for Biomedical Research Involving Animals. (1st ed.) ERIC Clearinghouse, Geneva, Switzerland.

Correia, B. R., G.G.P. Carvalho, R.L. Oliveira, A.J.V. Pires, O.L. Ribeiro, R.R. Silva, and B.M.A. Carvalho. 2016. Production and quality of beef from 
young bulls fed diets supplemented with peanut cake. Meat Sci. 118:157-163.

Cruz, C.D., A.J. Regazzi, and P.C.S. Carneiro. 2012. Modelo biométrico aplicado ao melhoramento genético. Viçosa: UFV, 2012. 1, 514.

Cruz, O. T.B., M.V. Valero, F. Zawadzki, D.C. Rivaroli, R.M. Prado, B.S. Lima, and I.N. Prado. 2014. Effect of glycerine and essential oils (Anacardium occidentale and Ricinus communis) on animal performance, feed efficiency and carcass characteristics of crossbred bulls finished in a feedlot system. Ital. J. Anim. Sci. 13:3492.

Destefanis, G., M.T. Barge, A. Brugiapaglia, and S. Tassone.2000. The use of principal component analysis (PCA) to characterize beef. Meat Sci. $56: 255-259$

Donkin, S.S., S.L. Koser, H.M. White, P.H. Doane, and M.J. Cecava. 2009. Feeding value of glycer$\mathrm{ol}$ as a replacement for corn grain in rations fed to lactating dairy cows. J. Dairy Sci. 92:5111-5119.

Ducatti, T., I.N. Prado, P.P. Rotta, R.M. Prado, D. Perotto, D. Maggioni, and J.V. Visentainer. 2009. Chemical composition and fatty acid profile in crossbred (Bos taurus vs. Bos indicus) young bulls finished in a feedlot. Asian Australas. J. Anim. Sci. 22:433.

Eiras, C. E., J.A. Marques, R. M. Prado, M. V. Valero, E. G. Bonafé, F. Zawadzki, D. Perotto, and I. N. Prado. 2014. Glycerine levels in the diets of crossbred bulls finished in feedlot: carcass characteristics and meat quality. Meat Sci. 96:930936.

El-Nor, S.A., A.A. AbuGhazaleh, R.B. Potu, D. Hastings, and M.S.A. Khattab. 2010. Effects of differing levels of glycerol on rumen fermentation and bacteria. Anim. Feed Sci. Technol. 162:99-105.

Françozo, M.C., I.N. Prado, U. Cecato, M.V. Valero, F. Zawadzki, O.L. Ribeiro, R.M. Prado, and J.V. Visentainer. 2013. Growth performance, carcass characteristics and meat quality of finishing bulls fed crude glycerin-supplemented diets. Braz. Arch. Biol. Technol. 56:327-336.

Gardner A.L. 1986. Técnicas de pesquisa em pastagem e aplicabilidade de resultados em sistema de produção. IICA/EMBRAPA CNPGL. 197-205
Hankins, O.G., and P.E. Howe. 1946. Estimation of the composition of beef carcass and cuts. Washington: Unite State Department of Agriculture, 1946.

Hernández, P., M. Pla, M.A. Oliver, and A. Blasco. 2000. Relationships between meat quality measurements in rabbits fed with three diets of different fat types and content. Meat Sci. 55:379-384.

HMSO. 1994. England Department of Health Nutritional. Aspects of cardiovascular disease. Report on Health and Social Subjects 46:37-46.

ISO. 1978. Animal and Vegetable Fats and Oils Preparation of Methyl Esters of Fatty Acids. Method ISO 5509.International Organization for Standardization, Geneva, Switzerland.

Karlsson, A. 1992. The use of principal component analysis (PCA) for evaluation results from pig meat quality measurements. Meat Sci. 31:423433.

Kearl, L.C. 1982. Nutrient Requirements of Ruminants in Developing Countries. 1st ed. International Feedstuffs Institute, Utah Agricultural Experiment Station, Utah State University, Utah, UT, USA. 82

Lee, S.Y., S.M. Lee, Y.B. Cho, D.K. Kam, S.C. Lee, C.H. Kim, and S. Seo. 2011. Glycerol as a feed supplement for ruminants: In vitro fermentation characteristics and methane production. Anim. Feed Sci. Technol. 166:269-274.

Mach, N., A. Bach, and M. Devant. 2009. Effects of crude glycerin supplementation on performance and meat quality of Holstein bulls fed high-concentrate diets. J. Anim.Sci. 87:632-638.

Maggioni, D., J.A. Marques, D. Perotto, P.P. Rotta, T. Ducatti, M. Matsushita, R.R. Silva, and I.N. Prado. 2009. Bermuda grass hay or sorghum silage with or without yeast addition on performance and carcass characteristics of crossbred young bulls finished in feedlot. Asian Australas. J. Anim. Sci. 22:206-215.

McMeniman, N.P. 1997 Methods of estimating intake of grazing animals. In: Reunião Anual da Sociedade Brasileira de Zootecnia, Simpósio sobre Tópicos Especiais em Zootecnia 34, 1997, Juiz de Fora. Anais Sociedade Brasileira de Zootecnia, 131-168. 
Mertens, D.R. 2002. Gravimetric determination of amylase-treated neutral detergent fiber in feeds with refluxing in beakers or crucibles: collaborative study. J. AOAC Int. 85:1217-1240.

Moreira, W.D.S., F.R.C. Miotto, J. Restle, R.L. Missio, J.N.M. Neiva, and R.V. Moreira. 2016. Crude glycerin levels in pearl millet-based diets for Nellore young bulls in feedlot. R. Bras. Zootec. 45:32-38.

Muller, L. 1987. Normas para avaliação de carcaças e concurso de novilhos (2nd ed.). Santa Maria: Universidade Federal de Santa Maria, 31.

Neto, A.J., J.D. Messana, A.F. Ribeiro, E.S. Vito, L.G. Rossi, and T.T. Berchielli. 2015. Effect of starch-based supplementation level combined with oil on intake, performance, and methane emissions of growing Nellore bulls on pasture. J. Anim. Sci. 93:2275-2284.

NRC. 2000. Nutrient Requirements of Beef Cattle (7th ed.). Natl. Acad. Press, Washington, DC.

Parsons, G.L., M.K. Shelor, and J.S. Drouillard. 2009. Performance and carcass traits of finishing heifers fed crude glycerin. J. Anim. Sci. 87:653657.

Pereira, L., A.J. Pires, G.G. Carvalho, R.V. Silva, J.I. Simionato, E.C. Lacerda, L.S. Bezerra, C.E. Eiras, and B.M.A. Carvalho. 2016. Nutritional Characteristics of Lambs Meat Fed Diets with Cotton Cake. J. Food Qual. 39:140-149.

Pouzo, L.B., A.M. Descalzo, N.E. Zaritzky, L. Rossetti, and E. Pavan. 2016. Antioxidant status, lipid and color stability of aged beef from grazing steers supplemented with corn grain and increasing levels of flaxseed. Meat Sci. 111:1-8.

Rivaroli, D.C., A. Guerrero, M.V. Valero, F. Zawadzki, C.E. Eiras, M. del Mar Campo, C. Sañudo, A.M. Jorge, and I.N. Prado. 2016. Effect of essential oils on meat and fat qualities of crossbred young bulls finished in feedlots. Meat Sci. 121:278-284.

Rotta, P.P., I.N. Prado, R.M. Prado, J.L. Moletta, R.R. Silva, and D. Perotto. 2009a. Carcass characteristics and chemical composition of the Longissimus muscle of Nellore, Caracu and Holstein-friesian bulls finished in a feedlot. Asian Australas. J. Anim. Sci. 22:598-604.
Rotta, P.P., R.M.. Prado, I.N. Prado, M.V. Valero, J.V. Visentainer, and R.R. Silva. 2009b. The effects of genetic groups, nutrition, finishing systems and gender of Brazilian cattle on carcass characteristics and beef composition and appearance: a review. Asian Australas. J. Anim. Sci. 22:17181734.

San Vito, E., J.F. Lage, A.F. Ribeiro, R.A. Silva, and T.T. Berchielli. 2015. Fatty acid profile, carcass and quality traits of meat from Nellore young bulls on pasture supplemented with crude glycerin. Meat Sci. 100:17-23.

SAS. 2009. SAS/STAT User guide, Version 9.0 SAS Institute Inc, Cary, NC, USA.

Scollan, N., J.F. Hocquette, K. Nuernberg, D. Dannenberger, I. Richardson, and A. Moloney. 2006. Innovations in beef production systems that enhance the nutritional and health value of beef lipids and their relationship with meat quality. Meat Sci. 74:17-33.

Silva, L.G.D., J.A. Torrecilhas, M.G. Ornaghi, C.E. Eiras, R.M. Prado, and I.N. Prado. 2014. Glycerin and essential oils in the diet of Nellore bulls finished in feedlot: animal performance and apparent digestibility. Acta Sci. Anim. Sci. 36:177-184.

Sniffen C.J., J.D. O'Connor, P.J. Van Soest, D.G. Fox, and J.B. Russell. 1992. A net carbohydrate and protein system for evaluating cattle diets: II - Carbohydrate and protein availability. J. Dairy Sci. 70:3562-3577.

Soliman, L.C., E.M. Andrucson, K.K. Donkor, J.S. Church, and B. Cinel. 2016. Determination of fatty acids in beef by liquid chromatographyelectrospray ionization tandem mass spectrometry. Food Anal. Methods 9:630-637.

Strada, E.S.O., R.R. Silva, G.G.P. Carvalho, L.P. Barbosa, F.L. Araújo, A.M. Pinheiro, and C.E. Eiras. 2015. Correlação entre o consumo e a deposição de ácidos graxos em bovinos suplementados com glicerina de baixa pureza em pastagens. Semin. Cienc. Agrar. 36:3269-3282.

Titgemeyer, E.C., C.K. Armendariz, D.J. Bindel, R.H. Greenwood, and C.A. Loest. 1997. Evaluation of titanium dioxide as a digestibility marker for cattle. J. Anim.Sci. 79:1059-1063. 
Titgemeyer, E.C., C.K. Armendariz, D.J. Bindel, R.H. Greenwood, and C.A. Löest. 2001. Evaluation of titanium dioxide as a digestibility marker for cattle. J. Anim.Sci. 79:1059-1063.

Trabue, S., K. Scoggin, S. Tjandrakusuma, M.A. Rasmussen, and P.J. Reilly. 2007. Ruminal fermentation of propylene glycol and glycerol. J. Agric. Food Chem. 55:7043-7051.

Wilm, H.G., D.F. Costello, and G.E. Klipple. 1994 Estimating forage yield by the double sampling method. Journal of the American Society of Agronomy 36:194-203.

Wood, J.D., M. Enser, A.V. Fisher, G.R. Nute, P.R. Sheard, R.I. Richardson, S.I. Hughes, and F.M. Whittington. 2008. Fat deposition, fatty acid composition and meat quality: A review. Meat Sci. 78:343-358.

Wright, A.M., J.G. Andrae, C.F. Rosso, M.C. Miller, E. Pavan, W. Bridges, and S.K. Duckett. 2015. Effect of forage type with or without corn supplementation on animal performance, beef fatty acid composition, and palatability. J. Anim.Sci. 93:5047-5058.

Zawadzki, F., E.G. Bonafé, R.M. Prado, M.V. Valero, J.E.L. Visentainer, and I.N. Prado. 2013. Corn replace by glycerin and functional oils (Anacardium acid and Ricinoleic acid) as additive alternative in the diets of crossbred bulls finished in feedlot: carcass and Longissimus dorsi characteristics. Meat Sci. in press. 